\title{
Towards Healthy Aging with Physical Activity and Nutrition
}

Listya Tresnanti Mirtha*, Angela Tulaar, I Dewa Putu Pramantara

\begin{abstract}
Background. Indonesia has become the country with the highest elderly population in Southeast Asia which around 27 million people within 2020. Demographic bonus, where the productive age is higher than the non-productive age, should be optimized so that it becomes an opportunity to decrease the dependency ratio of the elderly over 65 years. However, increasing life expectancy has other implications which as the increase in health problems associated with the aging process, including the emergence of degenerative diseases. The concept of healthy aging formed due to the increase of public awareness to live within quality life and maintaining a healthy lifestyle through physical activity and good nutrition. Healthy aging is the process of developing and maintaining the functional ability that enables wellbeing in older age. Lifestyle improvement from the early stage will have a better effect on a person's lifelong health. Unfortunately, it is not widely known by the public, so awareness is not yet evident and benefits cannot be obtained optimally.

Objectives. Healthy aging is the process of developing and maintaining the functional ability that enables wellbeing in older age. The aim of this review is to raise awareness among the adult age group about the important role of physical activity and nutrition in achieving a healthy aging condition.

Discussion. American College of Sports Medicine (ACSM) and Centers for Disease Control and Prevention (CDC) recommend adults aged 18-65 year to participate in moderate-intensity aerobic physical activity for a minimum of 30 minutes on five days per week, or vigorous-intensity aerobic activity for a minimum of 20 minutes on three days per week. Moreover, recent WHO (2020) guideline towards physical activity and sedentary behavior recommend all adults to have moderate-intensity for 150-300 min or vigorous-intensity for 75-150 min per week. But this recommendation has not been able to reduce physical inactivity number in Indonesian society, especially adult and senior adult. There are some nutrition elements related to mobility health, mainly are protein, vitamin D, calcium, antioxidant and omega-3, and many studies report that Indonesian adults suffer deficiencies on these nutrition elements and cause health problems related to mobility. Health interventions should involved many stakeholders, e.g government, private sectors, NGO, mass media, and many more.

Conclusions: The concept of healthy aging and interventions related to this need to be recognized and implemented as early as possible to get optimal results, and preferably starting from adulthood. Health interventions carried out must be holistic and synergize between physical activity, nutrition, mental health and other factors that play a role. A community-based approach is the easiest and fastest way to change mindsets and behavior patterns, and can be implemented in the work environment or other communities.
\end{abstract}

Keywords. Healthy aging, physical activity, nutrition, preventive, adult

\author{
*Correspondent: \\ tresnanti.listya@ui.ac.id \\ Listya Tresnanti Mirtha \\ Community Medicine Department, Faculty of Medicine, Universitas Indonesia
}

\section{INTRODUCTION}

People worldwide are living longer. By 2050, the world's population aged 60 years and older is expected to total 2 billion, up from 900 million in 2015. Today, the population of people aged 80 years and older reaches 125 million. By 2050, there will be almost this many ( 120 million) living in China alone, and 434 million people in this age group worldwide. By $2050,80 \%$ of all older people will live in low- and middle-income countries. While, the shift in distribution of a country's population towards older ages - known as population aging - started in high-income countries (for example in Japan $30 \%$ of the population are already over 60 years old), it is now low- and middle-income countries that are experiencing the greatest change. By the middle of the century many countries for e.g. Chile, China, the Islamic Republic of Iran and the Russian Federation will have a similar proportion of older people to Japan. The same problem might experienced in Indonesia as well. The elderly population in Indonesia has increased significantly for the last 30 years with a population of 5.30 million people (about $4.48 \%$ ) in 1970 , increased to 18.10 million in 2010 , by the year of 2014 elderly population numbered 20.7 million people (around $8.2 \%$ ) and it is assumed that elderly population already reached 27 million $(9.9 \%)$ in 2020 . As shown by this data, Indonesia becomes a country with a very high growth acceleration for elderly population in 
the period 1990-2020, as well as an increase in life expectancy from 66.7 years to 70.5 years. Thus Indonesia entered the aging population which characterized by the percentage of elderly people reaching $10 \%$ by the year 2020.1,2,3,4

A longer life brings an opportunities, not only for older people and their families, but also for societies as a whole. Additional years provide the chance to contribute in many ways to their families and communities. Yet the extent of these opportunities and contributions depends heavily on one factor: health. There is, however, little evidence to suggest that older people today are experiencing their later years in better health than their parents. While rates of severe disability have declined in high-income countries over the past 30 years, there has been no significant change in mild to moderate disability over the same period. If people can experience these extra years of life in good health and if they live in a supportive environment, their ability to do the things they value will be little different from the younger person. If these added years are dominated by declines in physical and mental capacity, the implications for older people and for society are more negative. The increase in life expectancy in both adult and senior adult in Indonesia is encouraging, it also bring other consequences which is higher number of adult and elderly population and higher number of health issues due to aging process i.e. degenerative diseases that may cause disabilities. This consequences generate a new concept of healthy aging which is a very important concept to build a healthy and productive aging population in Indonesia. The concept of healthy aging includes several aspects, namely physical health, lifestyle, culture, psychosocial, and spirituality. ${ }^{2,3}$

World Health Organization (WHO) defines healthy aging as "the process of developing and maintaining the functional ability that enables well-being in older age." Functional ability is about having the capabilities that enable all people to be and do what they have reason to value. This includes a person's ability to meet their basic needs; to learn, grow and make decisions; to be mobile; to build and maintain relationships; and last but not least, to contribute to society. To achieve healthy aging, depend on many factors, and heavily depend on one's health. Lifestyle and behavioral changes in physical activity and nutrition consumption affect people health, and have a positive impact if the changes has been implemented since early adult. $^{2}$

Regardless of all the support systems from the government, awareness about healthy aging in adult and pre-senior groups is still low, while lifestyle and behavioral changes in physical activity and nutrition consumption affect people health, and have a positive impact if the changes has been implemented since early adult. ${ }^{2}$ Therefore, in this study, we aim to provide a more focused description and to raise awareness and understanding among the adult age group about the important role of physical activity and nutrition in achieving a healthy aging condition.-A brief search was conducted using the keywords physical activity, exercise, nutrition, and aging through PubMed, Google Scholar, and Scopus. The search included papers written between the year 2008 and 2020, with reviews that discussed the important role physical activity and nutrition play for the adult population in achieving a healthy aging state.

\section{DISCUSSION}

\section{Physical Activity And Nutrition Guideline For Age 45+}

In terms of physical activity, many guidelines are available. One of the well-known association, American College of Sports Medicine's (ACSM) and Centers for Disease Control and Prevention (CDC) gave similar recommendations, stating that all healthy adults aged 18-65 years should participate in moderate intensity aerobic physical activity for a minimum of 30 minutes on five days per week, or vigorous intensity aerobic activity for a minimum of 20 minutes on three days per week. ACSM and CDC also recommend that every adult should perform activities that maintain or increase muscular strength and endurance (e.g cycling and hiking) for a minimum of two days per week. Strength training, weightlifting, and resistance exercise are types of exercises that can be used to increase strength. Moreover, World Health Organization (WHO) also published its newest guideline for physical activity and sedentary behavior that suggest all adults to have moderate-intensity for $150-300 \mathrm{~min}$ or vigorous-intensity for $75-150$ min per week. ${ }^{5,6,7,8,9}$ All of these guidelines has been adopted by the Ministry of Health Indonesia, adapted to local conditions in Indonesia society and introduced to the community and implemented in health campaign program, known as GERMAS (Gerakan Masyarakat Hidup Sehat) and GENTAS (Gerakan Nusantara Tekan Angka Obesitas). While GERMAS encourage people to include physical activity as part of healthy daily habit, GENTAS provides more specific recommendations for physical activity which are moderate-intensity physical activity for $\mathbf{1 5 0}$ minutes or vigorous-intensity for 75 minutes per week, or combination of both. As for physical training, GENTAS based on FITT principles namely frequency -3 to 5 times per week and can be increased to 5 to 7 times per week; intensity - moderate intensity; type - aerobic and low impact training; and time - based on individual tolerance, ideally 30 minutes per day or 150 to 300 minutes per week. ${ }^{10,11,12,13}$

However, the available guidelines do not necessarily reduce the number of physical inactivity experienced in the community. According to Indonesian Basic Health Research (RISKESDAS) 2018, the proportion of low physical activity (less than 150 minutes per week) in Indonesia is $33,5 \%$ with the highest number in Jakarta $(47,8 \%)$ and the lowest in Bali $(26 \%)$. The proportion of people with sufficient physical activity decreases from $73.9 \%$ to $66.5 \%$ in all age from 2013 to 2018 . And other studies shown that $59 \%$ of office workers in Jakarta are less active and spend time to do sedentary activity as much as 471 minutes per day or nearly 8 hours per day. Low physical activity will caused health problem e.g obesity, which peaked at the late adult, and underweight due to loss of muscle mass and nutrition deprivation in 
pre-senior and senior age. RISKESDAS 2018 showed a raised proportion of overweight and obesity case from $8,6 \%$ (overweight) and $10,5 \%$ (obesity) in 2007 to more than twice-fold in 2018 (13,6\% for overweight, and $21,8 \%$ for obesity). ${ }^{13,14,15}$

Ministry of Health in Indonesia classify senior adult group start from 60 years of age, pre-senior adult group from 45 to 60 years of age, and adult from 18 to 45 years of age. Pre-senior age group is the time to prepare for adult to go to the senior stage, which is the focus and target for early healthcare prevention and intervention for their senior years. While Ministry of Health recommend to start early prevention and intervention at pre-senior age, health practitioners prefer to introduce preventive measures and education as early as adult group. This age group believed to show better result in lifestyle changes mostly in physical activity and nutrition aspects. $^{2}$

As healthy aging is the goal, initiating lifestyle and behavioral changes from earl adult is the best strategy, and focusing on workers health may be the best option in raising awareness in adult age group. Using communitybased approach will provide better control over the health program which is being implemented in the office A reward and punishment system can also be implemented to encourage changes in behavior related to lifestyle and physical inactivity, may implemented in larger scale, in the community, with support from government. For example, employee recruitment in some company have implemented restrictions related to body mass index and health status of the prospective employees. WHO defines incentive as form of rewards and punishments way that could be implemented as a consequence of specific action under organization and the place where they do any health-related action. ${ }^{16}$ Community-based approach will also give benefit in selfencouraging in people who involved by comparing the achievements of each other.

To have retention and advocacy of the Program, people need to observe and feel the improvement in daily activities and physical/medical marker. Qualitative improvement such as less pain, better range of motion, able to walk easier, strength improvement, and balance improvement, also being able to perform daily activities without complaint will be the main reason to stay in this programme. However, as is known, this qualitative change did not appear immediately so that at the initial stage of program introduction required support and strictness from the leader to ensure this program is continued before the benefits could be felt.

World Health Organization (WHO) give a basic standard for healthy diet in adults which should includes the following: fruit, vegetables, legumes (e.g. lentils and beans), nuts and whole grains (e.g. unprocessed maize, millet, oats, wheat and brown rice); at least 400 gram (i.e. five portions) of fruit and vegetables per day; less than $10 \%$ of total energy intake from free sugars, which is equivalent to 50 gram (or about 12 level teaspoons) for a person, but ideally is less than $5 \%$ of total energy intake for additional health benefits - free sugars are all sugars added to foods or drinks by the manufacturer, cook or consumer, as well as sugars naturally present in honey, syrups, fruit juices and fruit juice concentrates; less than $30 \%$ of total energy intake from fats - unsaturated fats (found in fish, avocado and nuts, and in sunflower, soybean, canola and olive oils) are preferable to saturated fats (found in fatty meat, butter, palm and coconut oil, cream, cheese, ghee and lard) and trans-fats of all kinds, including both industrially-produced trans-fats (found in baked and fried foods, and pre-packaged snacks and foods, such as frozen pizza, pies, cookies, biscuits, wafers, and cooking oils and spreads) and ruminant trans-fats (found in meat and dairy foods from ruminant animals, such as cows, sheep, goats and camels); and consumption of salt not more than 5 gram (equivalent to about one teaspoon) per day. ${ }^{17,} 18,19,20$

In Indonesia, first campaign on healthy dietary guidelines introduced in 1952, known as "4 Sehat,5 sempurna". However, this is only suggesting the food groups and put huge emphasize on milk intake, which is not completely relevant. The campaign for balanced nutrition improved over time and now known as Pedoman Gizi Seimbang or Balanced Nutrition Guidelines. This guideline comprises of four pillars including eat variety of food, monitor body weight, perform physical activity, and clean-living behavior. ${ }^{21,22}$

Several program or campaign on the nutrition developed in Indonesia for general populations are GERMAS, KADARZI, GERNAS, and other healthy eating movement program. GERMAS stands for Gerakan Masyarakat Hidup Sehat which emphasizes on 7 strategies in habituating healthy lifestyle in order to prevent various health problems. One of these 7 strategies focusing on nutrition is campaign to consume more vegetables and fruits. KADARZI stands for Keluarga Sadar Gizi, an implemented government programs to address nutritional problems in family basis. In the KADARZI concept, which is meant by a nutritionally conscious family is a family that is able to recognize nutrition and health problems of members of the family as well as beingable to overcome or seek help to overcome it. GENTAS stands for Gerakan Nusantara Tekan Angka Obesitas. GENTAS programs give recommendations regarding the amount of daily consumption, namely vegetable consumption should be twice the amount of carbohydrates, a minimum 5-6 portions of vegetables and 3 portions of fruits daily; protein consumption should be as much as carbohydrate intake; and consumption of fruits and vegetables at least equal to the amount of protein and carbohydrates intake altogether. ${ }^{10,11,12,23}$

Nutritional status also plays a part in having a good mobility and there are some nutrition elements which has bigger role, mainly are protein, vitamin $D$, calcium, antioxidant and omega-3. Many studies report that Indonesian adult suffer deficiencies on these nutrition elements and cause health problems related to mobility. Protein intake tends to decrease with increasing age, also in Indonesia most of the protein consumed comes from vegetable sources. People also reduce their protein intake because of false belief about protein consumption would increased fat and cholesterol level. 
Compared to Malaysia and Australia, Indonesia adult population has higher protein deficiency due to the lower animal product intake including meat, poultry, fish and dairy. Only $60 \%$ of Indonesian adult met their protein requirements for protein based on the RDA, compared with $92 \%$ Malaysian and $99 \%$ Australian. ${ }^{24,25,26,27,28}$ When talking about protein consumption, attention should also given to protein quality. Protein quality describes characteristics of a protein in relation to its ability to achieve defined metabolic actions. For this reason, in the present context of optimal protein intakes, discussion of "what sort" is equally relevant as the question of "how much." There are 2 important aspects of protein quality: 1) the characteristics of the protein and the food matrix in which it is consumed, and 2) the demands of the individual consuming the food, as influenced by age, health status, physiologic status, and energy balance. Multiple factors influence protein quality. ${ }^{29}$

There is deficiency in vitamin D among Indonesian people due to the avoidance of sun exposure, which has implication for risk of osteoporosis and reduction in muscle strength. The prevalence of vitamin D deficiency for female adult is $50 \%$ and senior adult is $35.1 \% .^{30,31}$ Calcium is required for the normal development and maintenance of the skeleton, as well as for the proper functioning of neuromuscular and cardiac function. It is stored in the bones and teeth, where it provides structure and strength. A higher daily calcium intake was also associated with lower systolic and diastolic blood pressures. Despite the benefit, more than $40 \%$ adult men and $60 \%$ adult women in Indonesia have insufficient calcium intake due to low intake of milk. Antioxidant deficiency also caused by low intake of fruit and vegetables. ${ }^{32,33,34}$

\section{Ecosystem For Targeting Public And Community}

In Malaysia, The Ministry of Health has implemented various campaigns and programs to encourage physical activity among the population. There had been national campaigns for cycling (in 2005) and 10,000 steps (in 2009). Physical activity has been a component of programs at schools (Young Doctor), universities (Healthy University Students,) communities (Healthy Communities Empower the Nation), and the workplace (Active Citizens are Productive Citizens). Community Health Promotion Centre, established throughout the country, provide weekly exercise sessions and exercise consultation to the public. ${ }^{35}$

In Singapore, Health Promotion Board (HPB) has introduced programs such as the Healthier Choice Symbol (HCS) and Healthier Dining Programme (HDP) to increase the availability of healthier options, as well as campaigns such as the Eat, Drink, Shop Healthy Challenge to incentivize healthier purchases. To further create a healthy food environment, HDB and HPB collaborated to include the provision of healthy meals as a consideration in Price-Quality tenders for new eating houses, awarding more points for tenderers that offer healthy meal options. In partnership with MOE and ECDA, HPB has also implemented healthy meals programs in all mainstream schools and 8 in 10 preschools, to inculcate healthy eating habits from young. These efforts are complemented by health education outreach in schools in partnership with stakeholders such as South-West Community Development Council, Sengkang General Hospital, and National Youth Achievement Award (NYAA) Council; and at workplaces where HPB works with industry partners to roll out relevant workplace health promotion programmes such as workshops and health coaching. To encourage exercise, HPB, SportSG, and People's Association offer a wide range of physical activity programs and sport facilities island-wide. Singapore Ministry of Education also makes facilities and sports equipment available beyond the formal curriculum time to encourage better utilization. There are targeted programmes, such as those that cater to at-risk Professional, Managers, Executives and Technicians (PMET) at the workplace to increase the adoption of a more active lifestyle. For seniors, Active Aging Programmes (AAPs) are also made available at over 600 locations island-wide where the elderly can participate in group exercises and health workshops. ${ }^{36}$

Creating healthy aging culture in Indonesia will need involvement from many stakeholders and partners to support lifestyle changes especially in terms of physical activities and nutritional intake. Every program with public-based or community-based have the same objective to increase the health status of every individual by intervening healthy lifestyle and keep ensuring individual's safety, comfort and security.

Private sectors can contribute in building healthy lifestyle and give encouragement and support to maintain these lifestyle changes. Several companies take an interest in their employee nutrition intake thus designed a proper and appropriate nutrition program to be applied in the office. A good nutrition program includes educational programs regarding nutrition provided to employees as well as providing food with adequate and appropriate nutritional value for employees lunch. This strategy can be implemented in a healthy aging programme that will be carried out by the government.

In increasing awareness in terms of physical activity and nutrition among the general public, especially in adult groups, we should consider to develop integrated applications between physical activity, nutritional intake, and other things that also play a role in healthy aging, e.g adequacy of daily water intake, stress factors, sleep patterns as a tools on population early health screening. Indicators for physical activity can include simple things such as activities carried out using the motion sensor (walking, running, or other sports activities) as well as a warning system if someone sits still for a certain period of time, combined with nutrition programme such as body weight, body mass index, basal metabolic rate, and added calorie requirement figures based on physical activity undertaken. This application is also expected to provide recommendations regarding the number of calories burned by doing certain physical activities i.e within 30 minutes, as well as recommendations for calories contained in the food menu portions including Indonesian specialties food e.g nasi padang, nasi rawon. 
Indonesian government can develop policies aimed at increasing access to active transportation and the provision of facilities and opportunities for physical activity at the workplace would contribute toward increasing physical activity levels. Other policies providing for tax exemption for the improvement of opportunities for workers to engage in physical activity could help ensure willing acceptance of employers, potentially increasing workplace physical activity.

\section{CONCLUSION}

In creating a healthy society based on the concept of healthy aging, health interventions should be carried out early and can be started from adulthood i.e. starting from the age of 18 years. These changes must be holistic and work in synergy between physical activity, nutrition, and other factors that also play a role. Community-based approach is the easiest and fastest way to change person's mindsets and behavior, and can be implemented in the working environment or other communities.

\section{ACKNOWLEDGEMENT}

The authors would like to acknowledge the funding contribution of Danone SN Indonesia for the publication for this article.

\section{REFERENCE}

1. Officer, A. \& de la Fuente-Núñez, V. A global campaign to combat ageism. Bull. World Health Organ. 96, 295 (2018).

2. (WHO), W. H. O. Ageing: Healthy ageing and functional ability. Viitattu 8, 2020 (2020).

3. Organization, W. H. World report on ageing and health. (World Health Organization, 2015).

4. Indonesia, K. K. R. Situasi lanjut usia (lansia) di Indonesia. Pus. Data Dan Inf. Kementeri. Kesehat. Republik Indones. (2016).

5. Services, U. S. D. of H. and H. Physical Activity Guidelines for Americans 2nd edition. Recuperado el 2, diciembre, 2018 https://health. gov/paguidelines/secondedition/pdf. Phys. pdf (2018).

6. Piercy, K. L. et al. The physical activity guidelines for Americans. Jama 320, 2020-2028 (2018).

7. Chodzko-Zajko, W. J. Exercise and physical activity for older adults. Kinesiol. Rev. 3, 101-106 (2014).

8. Garber, C. E. et al. American College of Sports Medicine position stand. Quantity and quality of exercise for developing and maintaining cardiorespiratory, musculoskeletal, and neuromotor fitness in apparently healthy adults: guidance for prescribing exercise. Med. Sci. Sports Exerc. 43, 1334-1359 (2011).

9. Thompson, D. L. Fitness Focus Copy-and-Share: Walking for Health. ACSMs. Health Fit. J. 12, 4 (2008).

10. RI, K. Buku Panduan Germas, Gerakan Masyarakat Hidup Sehat. Jakarta Kemenkes RI (2016).
11. KEMENTERIAN KESEHATAN, R. I. MEDIAKOM EDISI 97.

12. KEMENKES, R. I. Panduan Pelaksanaan Gerakan Nusantara Tekan Angka Obesitas (GENTAS). (2017).

13. RI, K. Laporan hasil riset kesehatan dasar (Riskesdas) Indonesia tahun 2013. Jakarta Kemenkes RI (2013).

14. Statistik, B. P. Statistik sosial budaya... (Badan Pusat Statistik (BPS), 2009).

15. Abadini, D. \& Wuryaningsih, C. E. Determinan aktivitas fisik orang dewasa pekerja kantoran di Jakarta tahun 2018. J. Promosi Kesehat. Indones. 14, 15-28 (2019).

16. Organization, W. H. The world health report 2000: health systems: improving performance. (World Health Organization, 2000).

17. Organization, W. H. Diet, nutrition, and the prevention of chronic diseases: report of a joint WHO/FAO expert consultation. vol. 916 (World Health Organization, 2003).

18. Organization, W. H. Guideline: sugars intake for adults and children. (World Health Organization, 2015).

19. Organization, W. H. Guideline: Sodium intake for adults and children. (World Health Organization, 2012).

20. DepKes. Peraturan Menteri Kesehatan Republik Indonesia No 75 Tahun 2013. 2, 1-39 (2013).

21. Seimbang, P. G. BERITA NEGARA. 1-97 (2014).

22. Jahari, A. B. Keluarga Sadar Gizi (kadarzi) dalam menuju gizi baik untuk semua. Gizi Indones. 28, (2005).

23. Indonesia, S. Konsumsi Kalori dan Protein Penduduk Indonesia dan Provinsi Maret 2010.

24. Aris, T., Ahmad, N. A. \& Tee, G. H. National health and morbidity survey 2014: Malaysian adults nutrition survey (MANS. (Institute For Public Health, 2014).

25. Kirk, M. D. et al. Food Safety: Foodborne Disease in Australia: The OzFoodNet Experience. Clin. Infect. Dis. 47, 392-400 (2008).

26. Nisa, F. Z., Probosari, E. \& Fitranti, D. Y. Hubungan asupan omega-3 dan omega-6 dengan kadar trigliserida pada remaja 15-18 tahun. (2017).

27. Satria, A. Politik Kelautan dan Perikanan. (Yayasan Pustaka Obor Indonesia, 2015).

28. Millward, D. J., Layman, D. K., Tomé, D. \& Schaafsma, G. Protein quality assessment: impact of expanding understanding of protein and amino acid needs for optimal health. Am. J. Clin. Nutr. 87, 1576S-1581S (2008).

29. Setiati, S. Pengaruh pajanan sinar ultraviolet $b$ bersumber dari sinar matahari terhadap konsentrasi vitamin $D(25(\mathrm{OH}) \mathrm{D})$ dan hormon paratiroit pada perempuan usia lanjut Indonesia. Kesmas J. Kesehat. Masy. Nas. (National Public Heal. Journal) 2, 147-153 (2008).

30. Yosephin, B., Khomsan, A., Briawan, D. \& Rimbawan, R. Peranan Ultraviolet B Sinar Matahari terhadap Status Vitamin D dan Tekanan 
Darah pada Wanita Usia Subur. Kesmas J. Kesehat. Masy. Nas. (National Public Heal. Journal) 256-260 (2014).

31. Prasetyo, T. J., Hardinsyah, H., Baliwati, Y. F. \& Sukandar, D. The application of probability method to estimate micronutrient deficiencies prevalence of Indonesian adults. J. Gizi dan Pangan 13, 17-26 (2018).

32. Hayati, S. \& Herwana, E. Peningkatan asupan kalsium menghambat penurunan kepadatan tulang pada perempuan pascamenopause. J. Biomedika dan Kesehat. 1, 145-151 (2018).

33. Widjaya, I., Rumawas, M. \& Kidarsa, B. Hubungan Antara Asupan Kalsium Dengan Tekanan Darah: Sebuah Studi Pada Penduduk Indonesia Dewasa Berusia 30 Tahun. Ebers Papyrus 16, 13 (2017).
34. Khoo, S., Poh, B. K., Suhaimi, S. A., Chong, K. H. \& Varela, A. R. Physical Activity Promotion in Malaysia: Challenges and Opportunities. Front. Public Heal. 8, (2020)

35. Tobi, S. N. M., Masrom, M., Rahaman, S. A. S. A. \& Mohammed, A. MyHEALTH portal: Malaysia national web-based health information service for public well-being. Adv. Sci. Lett. 23, 28532856 (2017)

36. Soon, G., Koh, Y. H., Wong, M. L. \& Lam, P. W. Obesity prevention and control efforts in Singapore. Natl. Bur. Asian Res. Washingt. (2008) 